\title{
Comparison of soil chemical and microbial properties in monoculture larch and mixed plantations in a temperate forest ecosystem in Northeast China
}

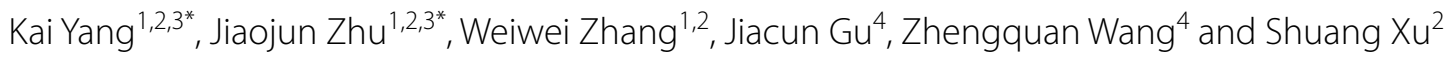

\begin{abstract}
Background: The introduction of broadleaved tree species in monoculture larch plantations to establish mixed plantations is a feasible way to improve soil properties. However, our understanding of how mixed plantations of larch and broadleaved tree species affect soil properties, particularly microbial community structures and functions, remains limited. We compared three paired monoculture larch (Larix gmelinii) and mixed [L. gmelinii-Fraxinus mandshurica (a dominant broadleaved species)] plantations to investigate the effect of a larch-broadleaved tree species combination on the carbon (C) and nitrogen ( $\mathrm{N}$ ) content, abundance and composition of microbial communities, and enzyme activities associated with litter and soil.

Results: The bacterial abundance in the litter, soil $\mathrm{N}$ availability, $\mathrm{pH}$ and electronic conductivity were significantly higher in the mixed-species plantation in comparison with those of the monoculture plantation. However, in the litter of mixed-species plantation, the relative levels of Agaricomycetes fungi were lower than those of the monoculture plantation, indicating that soil fungal communities were affected more than bacterial communities. In contrast, soil in the mixed-species plantation showed increased exoglucanase and $\mathrm{N}$-acetyl- $\beta$-glucosaminidase activities. However, the $\mathrm{C}$ and $\mathrm{N}$ levels, $\delta^{13} \mathrm{C}$ and $\delta^{15} \mathrm{~N}$ values, and fungal abundance in litter and soil were not significantly different between the monoculture and mixed-species plantations.
\end{abstract}

Conclusions: Our findings suggest that fungal community compositions and enzyme activities are sensitive to the introduction of broadleaved tree species into larch plantations. Thus, these parameters can be used as important indicators to evaluate the effects of tree species selection on soil restoration.

Keywords: Monoculture larch plantation, Bacterial community, Fungal community, Enzyme activity

\section{Introduction}

The total area of monoculture and mixed-species plantations in China is the largest of any nation globally, covering 69.3 million ha in 2014. Approximately 50\% of the country's tree plantations are coniferous monocultures

\footnotetext{
*Correspondence: kyang@iae.ac.cn; jiaojunzhu@iae.ac.cn

${ }^{1}$ CAS Key Laboratory of Forest Ecology and Management, Institute of Applied Ecology, Chinese Academy of Sciences, 72 Wenhua Road, Shenyang 110016, People's Republic of China

Full list of author information is available at the end of the article
}

(State Forestry Administration 2014). However, in comparison with natural forests, the monoculture coniferous plantations affect forest ecological services, such as decreasing above- and below-ground biodiversity, causing soil acidification, and reducing soil carbon $(\mathrm{C})$, available nitrogen $(\mathrm{N})$, and phosphorus $(\mathrm{P})$ levels (Yang et al. 2010, 2013). The introduction of native tree species to coniferous stands may restore forest ecological services. For example, mixed forest stands could improve soil C sequestration and biodiversity (Wardle et al. 2004; Brassard et al. 2011; Xu et al. 2021). Soil microbes are 
important components of soil that can affect $\mathrm{C}$ and nutrient cycling in forest ecosystems (Bohlen et al. 2001). Furthermore, the compositions and activities of soil microbial communities are more sensitive to changes in forest composition than soil $\mathrm{C}$ and nutrient alterations (Pei et al. 2016; Gunina et al. 2017). However, only a few studies have focused on changes in microbial communities occurring in mixed plantations in temperate forest ecosystems (Thoms et al. 2010). Therefore, it is essential to understand the differences in the compositions and functions of microbial communities, as well as their relationships with soil properties in monoculture and mixed plantations.

Soil microorganisms are known as essential components of soil function (Harris 2009). Urbanová et al. (2015) reported that microbial community composition was determined by tree species. Tree species compositions affect microbial communities directly through litter and root quality and nutrient uptake, as well as indirectly by altering soil properties (Bach et al. 2010; Huang et al. 2013; Liu et al. 2019). Furthermore, distinct microbial communities are found in the soils of broadleaved and coniferous tree species (Weand et al. 2010; Zhang et al. 2021). Specifically, soil microbial communities are less abundant and active in pine forests than in deciduous forests in temperate regions (Chodak et al. 2016). Therefore, understanding how plantations with monoculture coniferous tree species and those with a mix of coniferous and broadleaved tree species affect soil microbial communities may help to develop suitable forest composition management strategies and enhance sustainable plantation productivity.

Microorganisms in soil produce extracellular enzymes to degrade large, insoluble macromolecules, allowing microbial communities to acquire nutrients and energy. Thus, soil enzymes can reflect the microbial functionality affecting $C$ and nutrient cycling (Kaiser et al. 2010). In general, $\beta$-glucosidases, proteases, $N$-acetyl- $\beta$ glucosaminidases, and phosphatases are crucial enzymes in $\mathrm{C}$ and nutrient cycles in soil. These enzymes can sensitively reflect changes in soil properties (Trasar-Cepeda et al. 2008; Cheeke et al. 2017). For instance, compared with soils of native tree species, invasive $\mathrm{N}$-fixing species (Falcataria moluccana) can dramatically alter the activities of $\beta$-glucosidase and phosphatase (Allison et al. 2006). These changes in soil enzyme activities may be related to microbial community structures that mainly result from altered fungal communities (Burke et al. 2011; Barbi et al. 2016). Monoculture and mixed plantations are characterized by different levels of litter quality that vary with tree species. These differences in litter qualities between monoculture and mixed plantations may affect microbial community structures and functions.
Larch (Larix spp.) is an important tree species used for timber in temperate regions throughout Asia. Monoculture larch plantations exhibit lower abundance, activity of soil microbial community, and soil $C$ sequestration, in comparison with adjacent natural forests (Yang et al. 2013; Zhang et al. 2017). In this study, we compared soil chemical properties and the compositions and functions of the soil microbial communities of L. gmelinii plantations and adjacent mixed-species plantations of L. gmelinii and Fraxinus mandshurica. We hypothesized that compared with monoculture plantations, mixed plantations can alter microbial community compositions, and the changes in microbial communities would be associated with distinct enzyme activities and soil chemical properties.

\section{Materials and methods Site description}

The experiment was carried out at the Maoershan Experimental Station $\left(45^{\circ} 21^{\prime}-45^{\circ} 25^{\prime} \mathrm{N}, 127^{\circ} 30^{\prime}-127^{\circ} 34^{\prime} \mathrm{E}\right)$ located in Heilongjiang Province, China. The local parent rock material is composed of granite bedrock, and the soil under study is a Hap-Boric Luvisol (Gong et al. 1999). The local climate is a continental monsoon climate with warm summers and cold winters. The mean annual temperature is $2.8{ }^{\circ} \mathrm{C}$ and the mean annual rainfall is approximately $700 \mathrm{~mm}$ (Wang et al. 2006).

Our study examined two plantations: monoculture $L$. gmelinii plantation (monoculture plantation) and adjacent mixed tree species of L. gmelinii and F. mandshurica plantation (mixed-species plantation). These two plantations were planted in 1986 with a planting grid of $1.5-2.0 \mathrm{~m}$. The mixed-species plantation is composed of line-mixed tree species with three rows of $F$. mandshurica $\times$ five rows of L. gmelinii. In this study, three paired, an independent monoculture plantation, and an adjacent mixed-species plantation were randomly selected. Thus, there were six plots in total, and each plot was $600 \mathrm{~m}^{2}$ (30 $\mathrm{m}$ in length and $20 \mathrm{~m}$ in width). In the year 2015, litter layers were $2.0-4.6 \mathrm{~cm}$ and $2.4-4.0 \mathrm{~cm}$ thick in the monoculture mixed-species plantations, respectively.

\section{Litter and soil sampling}

Aboveground litter and soil samples were collected in August 2015. To eliminate the edge effects, the sampling area was established within a fixed plot by excluding two rows of trees positioned within the border. From each plot, 15 litter samples (subplot: $20 \mathrm{~cm} \times 20 \mathrm{~cm}$ ) and soil cores $(5 \mathrm{~cm}$ in diameter) were obtained. Specifically, soil samples were collected halfway between the L. gmelinii and $F$. mandshurica rows of the mixed plantations. Thereafter, the soil samples were divided into $0-10$, $10-20$ and $20-30 \mathrm{~cm}$ layers. Fifteen litter or soil cores 
collected from the same layer in each plot were mixed to form a composite sample. In the laboratory, the litter samples were cut and sieved through a 2-mm mesh after removing visible root residues. Soil samples were also passed through a 2-mm mesh and separated into four parts. The first part was stored at $4{ }^{\circ} \mathrm{C}$ for the analyses of soil enzyme activity, $\mathrm{NH}_{4}{ }^{+}-\mathrm{N}$ and $\mathrm{NO}_{3}{ }^{-} \mathrm{N}$. The second part was frozen at $-20{ }^{\circ} \mathrm{C}$ for subsequent DNA extraction. The first and second parts of soil samples were analyzed within one week after soil sampling. The third part was air-dried for analyses of soil $\mathrm{pH}$ and electrical conductivity. The remaining samples were sieved through a $0.15-\mathrm{mm}$ screen for the measurement of soil $\mathrm{C}, \mathrm{N}, \delta^{13} \mathrm{C}$, and $\delta^{15} \mathrm{~N}$ values. The basic soil properties are presented in Table 1.

\section{Soil chemical properties}

The $\mathrm{C}$ and $\mathrm{N}$ concentrations, as well as $\delta^{13} \mathrm{C}$ and $\delta^{15} \mathrm{~N}$ values, were determined using an elemental analyzer coupled with an isotope ratio mass spectrometer (IsoPrime Ltd., Stockport, UK). $\mathrm{NH}_{4}{ }^{+}-\mathrm{N}$ and $\mathrm{NO}_{3}{ }^{-} \mathrm{N}$ were extracted with $2 \mathrm{M} \mathrm{KCl}$ and quantified using an autoanalyzer (AutoAnalyzer III, Germany). Soil pH and electrical conductivity were measured with a $\mathrm{pH} /$ electrical conductivity meter in a soil-to-water slurry at 1:2.5 (w/v).

\section{Soil enzyme activities}

The activities of five soil enzymes (phenol oxidase, exoglucanase, $\beta$-glucosidase, $N$-acetyl- $\beta$-glucosaminidase, and acid phosphatase) were used to assess the microbial community functioning. The phenol oxidase activity was determined by incubating soil or litter with
L-3,4-dihydroxyphenylalanine (DOPA) and quantifying the oxidized reaction product. Specifically, we mixed $0.5 \mathrm{~g}$ of fresh soil (or $0.2 \mathrm{~g}$ of fresh litter) in $4 \mathrm{ml}$ of $10 \mathrm{mM}$ DOPA and $3 \mathrm{ml}$ of $50 \mathrm{mM}$ sodium acetate buffer $(\mathrm{pH}$ 5.0). The mixture was then shaken for $40 \mathrm{~min}$ at $25^{\circ} \mathrm{C}$ and centrifuged. The absorbance of the filtrate was determined at $460 \mathrm{~nm}$ (Saiya-Cork et al. 2002). For exoglucanase, $\beta$-glucosidase, $N$-acetyl- $\beta$-glucosaminidase, and acid phosphatase, soil or litter samples were added to $4 \mathrm{ml}$ of sodium acetate buffer $(50 \mathrm{mM}, \mathrm{pH} 5.0)$ and $1 \mathrm{ml}$ of the $\mathrm{p}$-nitrophenyl- $\beta$ - $\mathrm{D}$-cellobioside, $\mathrm{p}$-nitrophenyl$\beta$-D-glucopyranoside, $N$-acetyl- $\beta$-glucosaminide, and p-nitrophenol phosphate substrate, respectively (except when measuring acid phosphatase activity, for which $0.2 \mathrm{ml}$ of toluene was used). Subsequently, the samples were incubated at $37^{\circ} \mathrm{C}$ for 1 or $2 \mathrm{~h}$, depending on the substrate used. At the end of the incubation period, $1 \mathrm{ml}$ of $\mathrm{CaCl}_{2}(0.5 \mathrm{M})$ and $4 \mathrm{ml}$ of $\mathrm{NaOH}(0.5 \mathrm{M})$ were added to terminate the reaction. The soil slurry was then centrifuged and measured at $410 \mathrm{~nm}$ (Tabatabai 1994; Parham and Deng 2000). Enzyme activities were also assayed for three blanks and three substrate controls.

\section{Microbial community analysis}

Each litter and soil sample was extracted using the PowerSoil $^{\circledR}$ DNA Isolation Kit (MoBio Laboratories, Carlsbad, Inc., CA, USA). Duplicate DNA extractions were performed for each litter or soil sample and pooled. The eluted DNA quality was determined via agarose gel electrophoresis and then stored at $-20{ }^{\circ} \mathrm{C}$. Real-time PCR assays of bacterial and fungal communities were analyzed using a LightCycler ${ }^{\circledR} 96$ System (Roche, Germany).

Table 1 The chemical properties in the litter and soil of the monoculture and mixed-species plantations

\begin{tabular}{|c|c|c|c|c|c|c|c|c|c|}
\hline Forest type & $\begin{array}{l}\text { Total C ( } \mathbf{g} \\
\left.\mathbf{k g}^{-1}\right)\end{array}$ & $\begin{array}{l}\text { Total N (g } \\
\left.\mathbf{k g}^{-1}\right)\end{array}$ & $C: N$ & $\delta^{13} \mathrm{C}(\% \circ)$ & $\delta^{15} \mathrm{~N}(\% \circ)$ & $\begin{array}{l}\text { Ammonium } \\
\left(\mathrm{mg} \mathrm{kg}^{-1}\right)\end{array}$ & $\begin{array}{l}\text { Nitrate (mg } \\
\mathbf{k g}^{-1} \text { ) }\end{array}$ & $\mathrm{pH}$ & 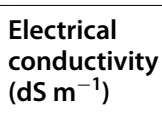 \\
\hline \multicolumn{10}{|l|}{ Litter } \\
\hline$P L$ & $370.4(15.0)$ & $19.9(0.6)$ & $18.6(0.3)^{*}$ & $-28.4(0.05)$ & $1.34(0.15)$ & nd & nd & nd & nd \\
\hline LF & $370.1(3.2)$ & $22.5(0.4)$ & $16.6(0.1)$ & $-28.1(0.05)$ & $1.11(0.17)$ & nd & nd & nd & nd \\
\hline \multicolumn{10}{|c|}{ 0-10 cm soil layer } \\
\hline$P L$ & $93.5(2.1)$ & $8.6(0.1)$ & $10.9(0.1)$ & $-26.1(0.03)$ & $6.32(0.07)$ & $1.66(0.31)$ & $76.1(7.8)$ & $5.22(0.07)$ & $0.27(0.02)$ \\
\hline LF & $101.9(6.7)$ & $9.5(0.5)$ & $10.8(0.2)$ & $-26.3(0.21)$ & $5.84(0.19)$ & $1.89(0.14)$ & $91.5(3.8)$ & $5.90(0.12)^{*}$ & $0.34(0.02)$ \\
\hline \multicolumn{10}{|c|}{ 10-20 cm soil layer } \\
\hline$P L$ & $49.1(1.1)$ & $5.4(0.1)$ & $9.1(0.1)$ & $-24.9(0.01)$ & $8.24(0.05)$ & $0.86(0.08)$ & $22.1(0.3)$ & $5.78(0.05)$ & $0.12(0.01)$ \\
\hline LF & $54.1(3.3)$ & $5.8(0.3)$ & $9.3(0.1)$ & $-25.2(0.12)$ & $7.91(0.23)$ & $1.38(0.04)^{*}$ & $30.8(1.0)^{*}$ & $5.89(0.11)$ & $0.15(0.01)^{*}$ \\
\hline \multicolumn{10}{|c|}{ 20-30 cm soil layer } \\
\hline$P L$ & $32.8(0.3)$ & $3.8(0.1)$ & $8.6(0.1)$ & $-24.5(0.02)$ & $8.70(0.04)$ & $1.04(0.06)$ & $11.6(1.2)$ & $5.80(0.02)$ & $0.07(0.01)$ \\
\hline LF & $33.2(1.4)$ & $3.8(0.2)$ & $8.7(0.1)$ & $-24.6(0.03)$ & $8.62(0.11)$ & $1.91(0.54)$ & $16.1(1.7)$ & $5.92(0.01)$ & $0.09(0.01)$ \\
\hline
\end{tabular}

Mean values for $n=3$ are presented. PL, monoculture L. gmelinii plantation; LF, mixed L. gmelinii-F. mandshurica plantation

* Represents significant differences between the monoculture and mixed plantations at the $P<0.05$ level 
Bacterial 16S ribosomal RNA (rRNA) and fungal 18S rRNA genes were quantified using the primer pair BAC338F/BAC805R and the probe BAC516F (Yu et al. 2005; Liu et al. 2012), respectively. Real-time PCR assays of bacteria and fungi were performed in a 20- $\mu$ l reaction volume using Premix Ex Taq ${ }^{\mathrm{TM}}$ and $\mathrm{SYBR}^{\circledR}$ Premix Ex Taq $^{\text {TM }}$ II (Takara, Japan), respectively. For each sample, three real-time PCR assays were performed and then the estimated copy values were averaged. For standard preparation, amplicons of each targeted gene were cloned with the PMDTM18-T vector (Takara, Japan) and transformed into Escherichia coli TOP10. Plasmids containing the respective targeted gene were extracted from clones using the MiniBEST Plasmid Purification Kit Ver. 4.0 (Takara, Japan) and linearized with a restriction enzyme. The plasmid DNA concentration was measured with a Nanodrop 2000 UV-Vis Spectrophotometer (Thermo Scientific). Data are shown as bacterial 16S rRNA and fungal $18 \mathrm{~S}$ rRNA gene copy values per gram of dry weight soil/litter.

We used the primers ITS3/ITS4 to amplify the ITS2 region of the fungal $\mathrm{rDNA}$ and the primers $341 \mathrm{~F} / 806 \mathrm{R}$ to amplify V3-V4 hypervariable regions of the bacterial $16 \mathrm{~S}$ rDNA (White et al. 1990; Takai and Horikoshi 2000). The cycling conditions involved initial denaturation at $98{ }^{\circ} \mathrm{C}$ for $1 \mathrm{~min}$ followed by 30 cycles with denaturation at $98^{\circ} \mathrm{C}$ for $10 \mathrm{~s}$, annealing for $30 \mathrm{~s}$ at $50{ }^{\circ} \mathrm{C}$, and extension for $1 \mathrm{~min}$ at $72^{\circ} \mathrm{C}$, with a final extension for $5 \mathrm{~min}$. Negative controls were included in the bacterial and fungal PCRs to detect contamination, and all PCRs remained contaminant free. Thereafter, PCR products were purified using the GeneJET Gel Extraction Kit (Thermo Scientific). Sequencing libraries were generated using the TruSeq ${ }^{\circledR}$ DNA PCR-Free Sample Preparation Kit (Illumina, USA) and the amplicons were subjected to sequencing on an Illumina HiSeq2500 platform.

Richness and diversity levels were calculated using the operational taxonomic units (OTUs)-based approach at the 0.03 level. Richness indices, including the abundance of observed species and Chao-1, were calculated to estimate the number of species or OTUs and measure taxonomic alpha diversity levels. Diversity was estimated using Simpson and Shannon diversity indices. Both bacterial and fungal sequences were submitted to the National Center for Biotechnology Information (NCBI) (SRP131257 and SRP131210, respectively).

\section{Statistical analyses}

All reported errors are standard errors with three sample replicates for each mean. Statistical analysis was carried out using SPSS 19.0. We used one-way analysis of variance (ANOVA) with Tukey's HSD test to determine the significant differences in litter and soil chemical properties and enzyme activities between monoculture and mixed-species plantations $(P<0.05)$. The Mantel test was conducted to assess the relationships between the soil properties and microbial community composition in each soil layer using the R software package (http:// www.r-project.org). Principal component analysis (PCA) was used to distinguish between microbial community compositions based on two forest types (Canoco 5.0).

\section{Results \\ Chemical properties of litter and soil in monoculture and mixed plantations}

Compared with the litter from the L. gmelinii plantation, the $\mathrm{C} / \mathrm{N}$ ratio was significantly lower in the mixedspecies plantation litter. The $\mathrm{NH}_{4}{ }^{+}-\mathrm{N}$ and $\mathrm{NO}_{3}{ }^{-}$-N levels increased by $39.6 \%$ and $60.5 \%$, respectively, in the $10-20$ $\mathrm{cm}$ soil layer of the mixed-species plantation compared to those of the monoculture plantation (Table 1). Soil $\mathrm{pH}$ and electronic conductivity also increased in the mixed plantation. In contrast, there were no significant differences in total $\mathrm{C}$ and $\mathrm{N}$, as well as $\delta^{13} \mathrm{C}$ and $\delta^{15} \mathrm{~N}$ values between the monoculture plantation and mixed-species plantation. Soil $\mathrm{C}$ and $\mathrm{N}$ contents ranged from 93.5$101.9 \mathrm{~g} \mathrm{~kg}^{-1}$ and $8.6-9.5 \mathrm{~g} \mathrm{~kg}^{-1}$ in the $0-10 \mathrm{~cm}$ soil layer, respectively. The $\mathrm{C}$ and $\mathrm{N}$ content and the $\mathrm{C} / \mathrm{N}$ ratio decreased with soil depth in both the monoculture plantation and mixed-species plantation, whereas the $\delta^{13} \mathrm{C}$ and $\delta^{15} \mathrm{~N}$ values increased with soil depth.

\section{Enzyme activities of litter and soil in monoculture and mixed plantations}

The enzyme activities of the mixed-species plantation were different than those of the monoculture plantation (Fig. 1). In the litter, $\beta$-glucosidase activities increased by $32.1 \%$, whereas the activities of phenol oxidase, exoglucanase, $N$-acetyl- $\beta$-glucosaminidase, and acid phosphatase did not significantly change in the mixed-species plantation. It should be noted that in the mixed plantation, changes in soil enzymes were mainly noted in the 0-10 cm layer. Specifically, the activities of exoglucanase and $N$-acetyl- $\beta$-glucosaminidase increased by $51.0 \%$ and $50.8 \%$, respectively, in the mixed plantation, whereas the activities of phenol oxidase, $\beta$-glucosidase, and acid phosphatase were similar in both the monoculture and mixed-species plantations. All the enzyme activities decreased with soil depth.

\section{Bacterial and fungal communities of litter and soil in monoculture and mixed plantations}

Total bacterial abundances observed in the litter were significantly higher for the mixed-species plantation than for the monoculture plantation, whereas total fungal abundances in litter did not significantly differ 


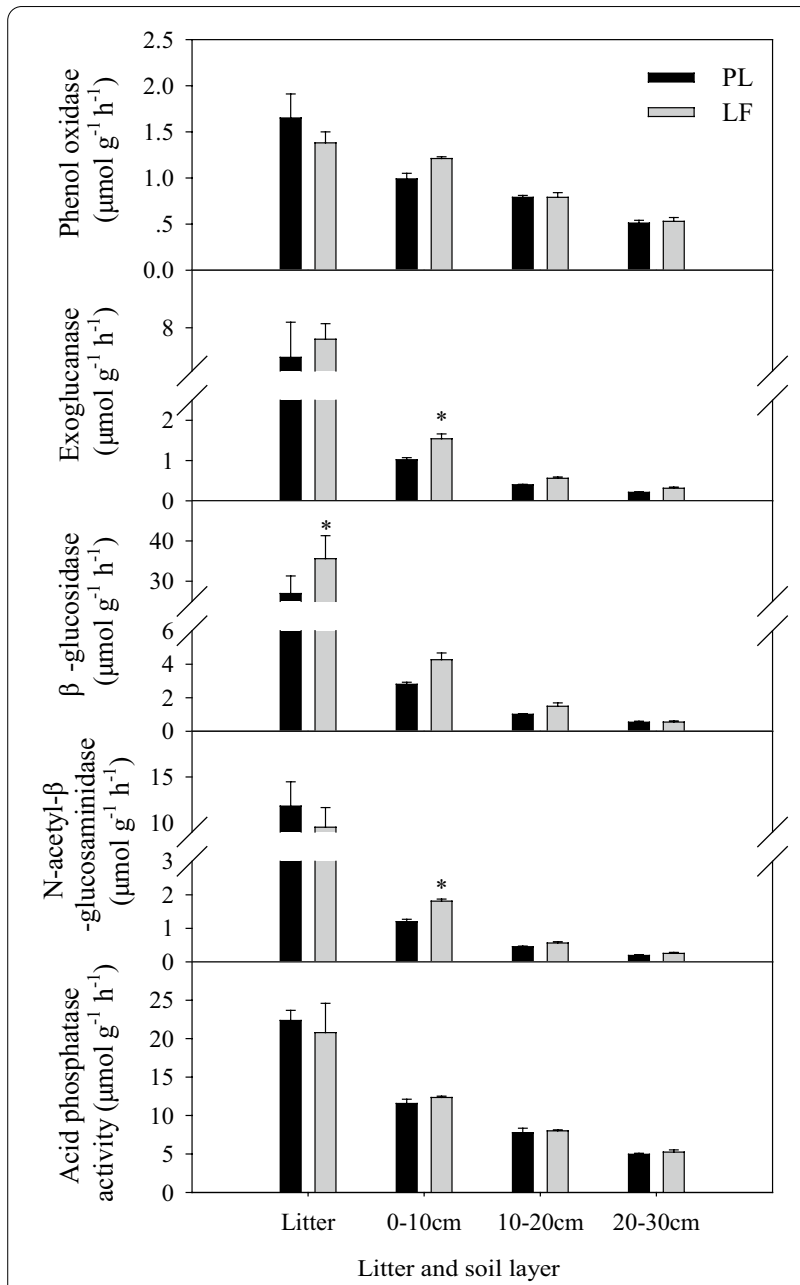

Fig. 1 Enzymatic activity of litter and soil in the monoculture Larix gmelinii plantation (PL) and mixed L. gmelinii-Fraxinus mandshurica plantation (LF). Values are presented as means $\pm \operatorname{SE}(n=3)$. * Denotes significant differences between the monoculture and mixed plantations at the $P<0.05$ level

between the monoculture and mixed-species plantations. In addition, no differences were found in soil bacterial and fungal abundances between the monoculture and mixed plantations (Fig. 2). In general, there was a reduction in bacterial and fungal abundances with increasing soil depth.

A total of 1107529 bacterial sequences and 1210558 fungal sequences were obtained from the 24 samples, including 6 litter samples and 18 soil samples. These sequences were grouped into 7113 OTUs of bacteria and 3211 OTUs of fungi at the $97 \%$ identity threshold. The number of observed species and calculated indices of Shannon diversity, Simpson diversity, and Chao-1 richness for bacterial and fungal communities did not differ between the monoculture and mixed-species

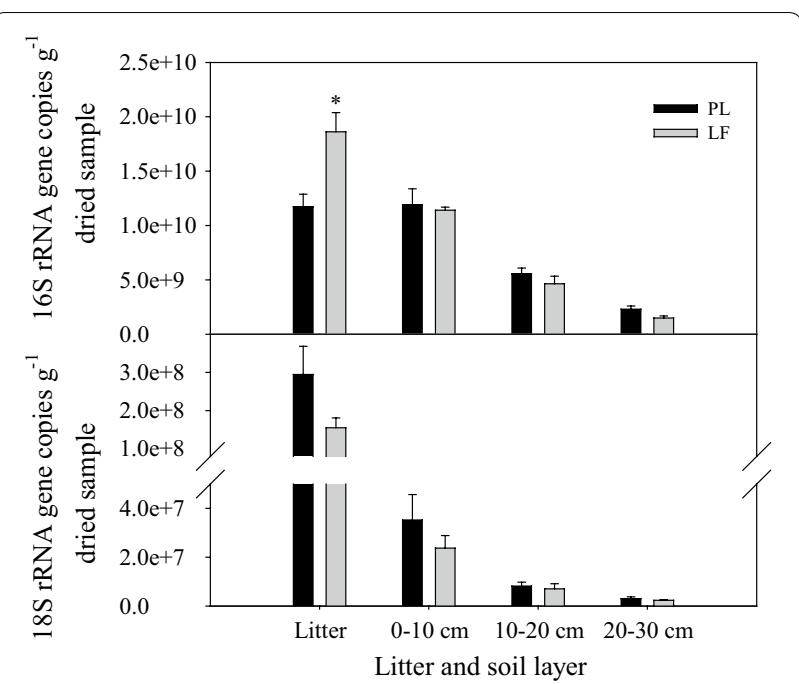

Fig. 2 Abundance of soil bacteria and fungi based on a quantitative PCR analysis comparing the monoculture Larix gmelinii plantation (PL) and mixed L. gmelinii-Fraxinus mandshurica plantation (LF). Values are presented as means \pm SE $(n=3)$. *Denotes significant differences between the monoculture and mixed plantations at the $P<0.05$ level

plantations, except for the Simpson diversity values of the $10-20 \mathrm{~cm}$ soil depth layer (Table 2).

The dominant phyla of bacteria identified in litter and soil included Proteobacteria, Acidobacteria, Verrucomicrobia, Bacteroidetes, and Gemmatimonadetes. Generally, the relative abundances of the phyla Proteobacteria and Verrucomicrobia decreased with soil depth, whereas Acidobacteria were most abundant in the $0-10 \mathrm{~cm}$ soil layer (Fig. 3). The levels of the rare bacterial phylum AD3 were significantly higher in the mixed plantation than in the monoculture plantation in the $0-10 \mathrm{~cm}$ and $10-20$ $\mathrm{cm}$ soil layers. A PCA based on the abundances of bacterial genera showed that litter and soil samples drawn from the monoculture plantation were separated from the mixed-species plantation (Fig. 4). The first two PCA axes could explain $54.7 \%$ of the variance in litter and soil layers.

Regarding the compositions of fungal communities, both litter and soil were dominated by Sordariomycetes, Leotiomycetes, Agaricomycetes, and Dothideomycetes. Furthermore, the relative abundance of Agaricomycetes was significantly higher in the monoculture plantation than in the mixed-species plantation (Fig. 3). Less abundant classes, such as Tremellomycetes, were also significantly affected by the mixed plantation. In the litter and soil layers, the PCA analysis could not distinguish the fungal community composition from the monoculture larch and mixed plantations (Fig. 4).

Mantel tests were used to assess the relationships between soil properties and microbial community 
Table 2 Comparison of species richness and alpha diversity indices of bacterial and fungal communities between the monoculture and mixed-species plantations

\begin{tabular}{|c|c|c|c|c|c|c|c|c|}
\hline \multirow[t]{2}{*}{ Forest type } & \multicolumn{4}{|c|}{ Bacterial community } & \multicolumn{4}{|c|}{ Fungal community } \\
\hline & $\begin{array}{l}\text { Observed } \\
\text { species }\end{array}$ & $\begin{array}{l}\text { Shannon } \\
\text { diversity }\end{array}$ & $\begin{array}{l}\text { Simpson } \\
\text { diversity }\end{array}$ & $\begin{array}{l}\text { Chao-1 } \\
\text { richness }\end{array}$ & $\begin{array}{l}\text { Observed } \\
\text { species }\end{array}$ & $\begin{array}{l}\text { Shannon } \\
\text { diversity }\end{array}$ & $\begin{array}{l}\text { Simpson } \\
\text { diversity }\end{array}$ & $\begin{array}{l}\text { Chao-1 } \\
\text { richness }\end{array}$ \\
\hline \multicolumn{9}{|l|}{ Litter } \\
\hline$P L$ & $2942(26)$ & $9.40(0.14)$ & $0.991(0.004)$ & $3343(27)$ & $951(20)$ & $6.66(0.21)$ & $0.973(0.004)$ & $1186(63)$ \\
\hline LF & $2854(46)$ & $9.58(0.09)$ & $0.996(0.001)$ & $3245(55)$ & 901 (96) & $6.55(0.46)$ & $0.968(0.010)$ & 1099 (106) \\
\hline \multicolumn{9}{|c|}{$0-10 \mathrm{~cm}$ soil layer } \\
\hline$P L$ & $2835(108)$ & $9.40(0.11)$ & $0.994(0.001)$ & $3278(136)$ & $939(65)$ & $6.67(0.06)$ & $0.970(0.005)$ & $1116(114)$ \\
\hline LF & $2915(141)$ & $9.61(0.13)$ & $0.996(0.001)$ & $3292(149)$ & $953(82)$ & $6.88(0.26)$ & $0.975(0.005)$ & $1082(89)$ \\
\hline \multicolumn{9}{|c|}{ 10-20 cm soil layer } \\
\hline$P L$ & $2801(66)$ & $9.39(0.11)$ & $0.994(0.001)$ & $3229(80)$ & $986(47)$ & $6.72(0.05)$ & $0.966(0.003)$ & $1211(99)$ \\
\hline LF & $2983(78)$ & $9.60(0.06)$ & $0.995(0.001)$ & $3392(47)$ & $1017(69)$ & $7.04(0.19)$ & $0.977(0.003)^{*}$ & $1220(120)$ \\
\hline \multicolumn{9}{|c|}{ 20-30 cm soil layer } \\
\hline$P L$ & 3055 (99) & $9.64(0.20)$ & $0.995(0.001)$ & $3508(104)$ & $1024(25)$ & $6.87(0.28)$ & $0.972(0.010)$ & $1356(36)$ \\
\hline LF & $2951(92)$ & $9.47(0.12)$ & $0.993(0.001)$ & $3363(65)$ & $1057(86)$ & $6.44(0.94)$ & $0.907(0.076)$ & $1263(122)$ \\
\hline
\end{tabular}

Mean values for $n=3$ are presented. PL, monoculture L. gmelinii plantation; LF, mixed L. gmelinii-F. mandshurica plantation

${ }^{*}$ Represents significant differences between the monoculture and mixed plantations at the $P<0.05$ level
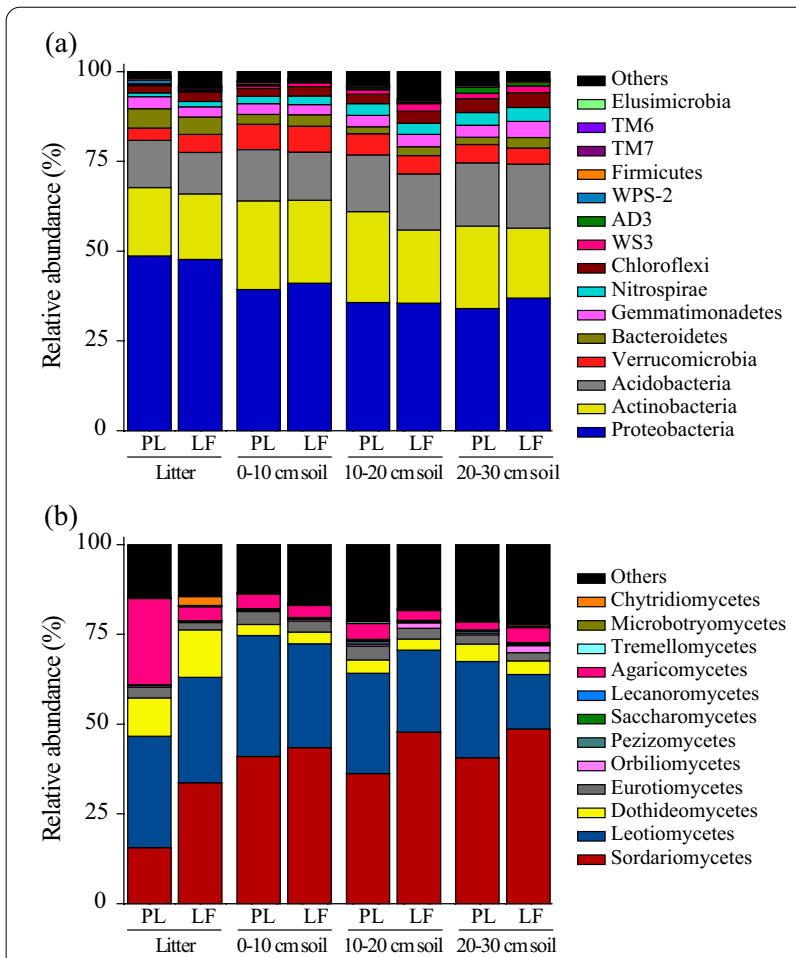

Fig. 3 Relative abundance of (a) bacterial phyla and (b) fungal classes of forest litter and soil of the monoculture Larix gmelinii plantation (PL) and mixed L. gmelinii-Fraxinus mandshurica plantation $(\mathrm{LF})$. Values are presented as means $\pm \mathrm{SE}(n=3)$ composition (Table 3). In the litter layer, only phenol oxidase activity $(r=0.770, P=0.006)$ displayed positive relationships with bacterial community composition. In the $0-10 \mathrm{~cm}$ soil layer, soil total $C(r=0.564, P=0.021)$ and $\mathrm{N}(r=0.500, P=0.025)$ showed significant positive correlation with bacterial community composition. Furthermore, the activities of $N$-acetyl- $\beta$-glucosaminidase $(r=0.315, \quad P=0.044)$ and phenol oxidase $(\mathrm{r}=0.695$, $P=0.007)$ were significantly correlated with fungal community composition. In the $10-20 \mathrm{~cm}$ soil layer, exoglucanase activity $(r=0.661, P=0.019)$ was also significantly correlated with fungal community composition. In the 20-30 cm soil layer, the Mantel tests showed soil total C $(r=0.673, P=0.031)$ and $\mathrm{N}(r=0.808, P=0.011)$ as being positively correlated with fungal community composition.

\section{Discussion}

This study led to two important findings. Firstly, we found that soil $\mathrm{C}$ and $\mathrm{N}$ levels did not differ between monoculture and mixed plantations. The high initial $\mathrm{C}$ and $\mathrm{N}$ contents of soils in the study area may be responsible for the absence of $\mathrm{C}$ and $\mathrm{N}$ content changes observed in the mixed plantation. Secondly, we found no differences in total fungal abundance between the two plantations. However, changes in fungal community compositions and enzyme activities were observed in the mixed plantation. Our results suggest that fungal community compositions and hydrolytic enzyme activities in mixed plantations could be used as important parameters for assessing soil restoration in temperate forest ecosystems. 
(a)

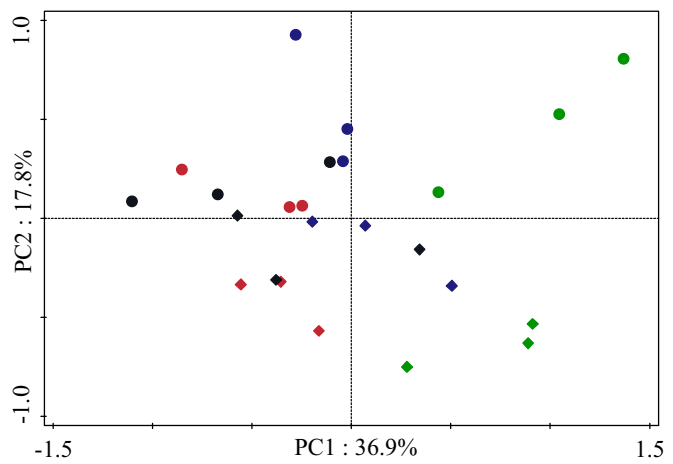

(b)

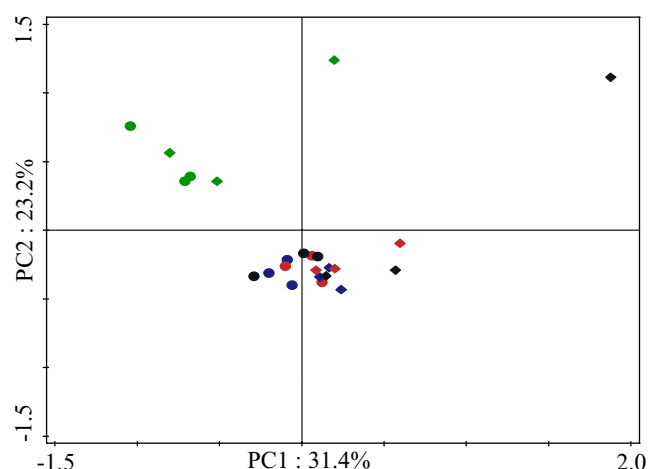

Fig. 4 Compositions of (a) bacterial and (b) fungal communities in forest litter and soil of the monoculture Larix gmelinii plantation (PL) and mixed L. gmelinii-Fraxinus mandshurica plantation (LF), as analyzed via principal component analysis. Circular shape, L. gmelinii plantation; diamond shape, mixed L. gmelinii-F. mandshurica plantation. Green, litter; blue, 0-10 cm soil layer; red, 10-20 cm soil layer; black, 20-30 cm soil layer

Table 3 The correlations ( $r$ value) and significance ( $P$ value) determined by the Mantel test between the soil properties and microbial community

\begin{tabular}{|c|c|c|c|c|c|c|c|c|}
\hline \multirow{2}{*}{$\begin{array}{l}\text { Soil } \\
\text { properties }\end{array}$} & \multicolumn{2}{|l|}{ Litter layer } & \multicolumn{2}{|c|}{$0-10 \mathrm{~cm}$ soil layer } & \multicolumn{2}{|c|}{$10-20 \mathrm{~cm}$ soil layer } & \multicolumn{2}{|c|}{$20-30 \mathrm{~cm}$ soil layer } \\
\hline & Bacteria & Fungi & Bacteria & Fungi & Bacteria & - & Bacteria & Fungi \\
\hline Total C & $0.481(0.085)$ & $0.002(0.367)$ & $0.564(0.021)$ & $-0.035(0.504)$ & $0.179(0.214)$ & - & $0.136(0.308)$ & $0.673(0.031)$ \\
\hline Total N & $0.343(0.118)$ & $-0.014(0.490)$ & $0.500(0.025)$ & $-0.043(0.482)$ & $0.154(0.196)$ & $-0.121(0.536)$ & $0.351(0.190)$ & $0.808(0.011)$ \\
\hline Exoglucanase & $-0.336(0.790)$ & $-0.298(0.832)$ & $0.413(0.092)$ & $0.485(0.069)$ & $-0.195(0.763)$ & $0.661(0.019)$ & $0.012(0.504)$ & $0.012(0.446)$ \\
\hline$\beta$-Glucosidase & $-0.563(0.956)$ & $-0.442(0.928)$ & $0.406(0.110)$ & $0.148(0.335)$ & $-0.090(0.392)$ & $-0.058(0.460)$ & $-0.403(0.951)$ & $-0.193(0.819)$ \\
\hline NAG & $-0.023(0.511)$ & $-0.236(0.790)$ & $0.140(0.251)$ & $0.315(0.044)$ & $0.433(0.139)$ & $-0.041(0.457)$ & $-0.297(0.768)$ & $-0.401(0.896)$ \\
\hline $\begin{array}{l}\text { Acid phos- } \\
\text { phatase }\end{array}$ & $-0.296(0.818)$ & $-0.223(0.781)$ & $-0.110(0.588)$ & $-0.164(0.632)$ & $-0.291(0.828)$ & $-0.058(0.503)$ & $-0.296(0.742)$ & $-0.301(0.826)$ \\
\hline Phenol oxidase & $0.770(0.006)$ & $0.305(0.175)$ & $0.161(0.282)$ & $0.695(0.007)$ & $-0.133(0.549)$ & $-0.081(0.524)$ & $-0.046(0.525)$ & $0.014(0.507)$ \\
\hline $\mathrm{pH}$ & nd & nd & $0.203(0.197)$ & $0.077(0.393)$ & $-0.061(0.528)$ & $-0.010(0.476)$ & $0.194(0.233)$ & $-0.010(0.500)$ \\
\hline EC & nd & nd & $0.103(0.319)$ & $0.249(0.182)$ & $0.229(0.149)$ & $-0.090(0.610)$ & $0.133(0.346)$ & $0.172(0.310)$ \\
\hline Nitrate & nd & nd & $0.161(0.272)$ & $0.242(0.197)$ & $-0.003(0.447)$ & $0.258(0.103)$ & $0.067(0.397)$ & $-0.023(0.521)$ \\
\hline Ammonium & nd & nd & $-0.377(0.928)$ & $0.361(0.167)$ & $-0.126(0.668)$ & $0.228(0.169)$ & $0.204(0.415)$ & $0.376(0.288)$ \\
\hline
\end{tabular}

NAG $N$-acetyl- $\beta$-glucosaminidase, EC electrical conductivity

The bold font represents significant correlations between microbial community and soil properties at the $P<0.05$ level

\section{Effects of mixing larch and broadleaved tree species on the chemical properties of litter and soil}

In a forest ecosystem, tree species affect soil chemical properties through variations in leaf litter quality and fine root biomass (Diers et al. 2021). An earlier study demonstrated that coniferous and broadleaved forests can accumulate more $\mathrm{C}$ in soil than evergreen broadleaf forests, based on a 1974 soil sample database (Chiti et al. 2012). Furthermore, compared to monoculture plantations, afforestation with a mixture of tree species, especially that with $\mathrm{N}$-fixing species, has been found to increase the levels of soil C and $\mathrm{N}$ contents (Huang et al. 2014; Liu et al. 2017). Our results show that total $\mathrm{C}$ and $\mathrm{N}$ contents do not change in the forest litter and soil of monoculture and mixed-species plantation stands. The higher initial levels of soil $\mathrm{C}$ and $\mathrm{N}$ contents observed may result in lower accumulation of $\mathrm{C}$ and $\mathrm{N}$ in the soil after afforestation (Gilmore and Boggess 1963).

Mixed-species plantations exhibited higher levels of soil ammonium $\left(\mathrm{NH}_{4}^{+}\right)$and nitrate $\left(\mathrm{NO}_{3}{ }^{-}\right)$than L. gmelinii plantations. This result is in line with the findings of other studies from subtropical and tropical areas (Rachid et al. 2013; Yu et al. 2015). Importantly, mixed tree species can increase soil $\mathrm{N}$ availability and improve soil ammonification, nitrification rates, and $\mathrm{N}$ mineralization, thereby accelerating $\mathrm{N}$ cycling in the upper $10 \mathrm{~cm}$ layer (Kooch and Bayranvand 2017). 
Fine root biomass may also affect soil $\mathrm{N}$ availability. Mei et al. (2008) reported that the fine root biomass was positively correlated with soil $\mathrm{N}$ availability in the same study area, and the fine root biomass was higher in F. mandshurica plantations than that in L. gmelinii plantations. Although soil available $\mathrm{N}$ differed between the monoculture and mixed-species plantations, further research on soil available $\mathrm{N}$ in different seasons, and with different soil $\mathrm{N}$ mineralization, and fine root biomass in monoculture and mixed-species plantations would help evaluate the generality of our results. In agreement with the findings of previous mixed plantation studies, the soil pH level in the $0-10 \mathrm{~cm}$ layer was higher in mixed-species plantations compared to that observed in monoculture plantations. This decrease in soil acidification likely resulted from changes in litter quality and root exudates and increased the uptake of cations by trees (Gunina et al. 2017). Therefore, afforestation with mixed tree species can alleviate soil acidification and increase $\mathrm{N}$ availability, although it does not increase the $\mathrm{C}$ and $\mathrm{N}$ supplies in soils.

In our study, soil $\delta^{13} \mathrm{C}$ and $\delta^{15} \mathrm{~N}$ levels increased with soil depth, which is in line with the results reported in other studies of forest ecosystems (Hobbie and Ouimette 2009; Guillaume et al. 2015; Gautam et al. 2017). Dijkstra et al. (2006) found that the levels of $\delta^{13} \mathrm{C}$ and $\delta^{15} \mathrm{~N}$ in microbial products gradually increase with soil formation. Although we did not find differences in the $\delta^{13} \mathrm{C}$ and $\delta^{15} \mathrm{~N}$ levels in soils between the monoculture and mixed plantations, our results showed that soil enzyme activity levels are higher in mixed-species plantations than in monoculture plantations. This finding may be because the higher $\delta^{13} \mathrm{C}$ and $\delta^{15} \mathrm{~N}$ levels in the litter or roots of monoculture plantations tend to mask microbial fractionation processes, compared to those in the mixed-species plantations.

\section{Effects of mixing larch and broadleaved tree species on microbial community composition and enzyme activity} Tree species are an important factor affecting the activity of extracellular enzymes. In general, compared to those of the monoculture plantation, the activity levels of $\beta$-glucosidase, exoglucanase, and $N$-acetyl$\beta$-glucosaminidase were higher in the mixed plantation forest litter and soil. In previous studies on mixed tree species, elevated enzyme activity levels have been found (Allison et al. 2006; Singh et al. 2012). Moreover, microbial enzymes in the litter and soil of monoculture and mixed-species plantations differed. For example, $\beta$-glucosidase activity increased in the litter but not in the soil of the mixed plantation, whereas the activities of exoglucanase and $N$-acetyl- $\beta$-glucosaminidase increased in the topsoil but not in the forest litter of the mixed plantation. $\beta$-Glucosidase is known to catalyze complex cellulose into simple sugars (Esen 1993). Changes in $\beta$-glucosidase activity in the litter may be related to shifts in the composition of the fungal community. Fungi may be more efficient than bacteria at acquiring available $\mathrm{C}$ and $\mathrm{N}$ or incorporating $\mathrm{C}$ and $\mathrm{N}$ into biomass. Given that $N$-acetyl- $\beta$-glucosaminidase is associated with $\mathrm{N}$ acquisition, an increase in $\mathrm{N}$ availability could reduce $N$-acetyl- $\beta$-glucosaminidase activity, depending on the forms of microbial allocation. However, both $N$-acetyl- $\beta$-glucosaminidase activity and available $\mathrm{N}$ content increased, suggesting a more complex interaction. Furthermore, other factors, such as soil microbial community alterations, may affect $\mathrm{N}$ availability. Rachid et al. (2013) found that mixed plantations increase soil $\mathrm{NO}_{3}{ }^{-}-\mathrm{N}$ levels through changes in $\mathrm{N}$ cycling genes. We found that soil enzyme activity levels decreased with soil depth. This result is consistent with those of other studies reporting exponential declines in soil enzyme activity with forest ecosystem soil depth (Venkatesan and Senthurpandian 2006; Stone et al. 2014).

The effect of mixed plantations on the composition of the microbial community can regulate enzyme-catalyzed processes. In the present study, the bacterial phyla Proteobacteria, Acidobacteria and Verrucomicrobia were dominant in monoculture and mixed-species plantations, in agreement with the findings of studies in other temperate forests, based on a high-throughput sequencing method (Li et al. 2014). We found that while the relative abundances of fungi at the class level were not related to enzyme activities, the abundances of some fungal genera were related. This result also indicates that enzymes serve as an estimate of functional community composition.

The mixed-species plantation did not alter fungal abundances, but it did change fungal community compositions. This finding is consistent with those of studies of other temperate forest ecosystems showing that total microbial biomass does not change depending on the tree species (Weand et al. 2010). However, mixed plantations can increase soil bacterial and fungal biomass levels, compared to those of monoculture plantations in subtropical forest ecosystems (Lucas-Borja et al. 2012; Huang et al. 2014), which suggests that tree species diversity plays a vital role in shaping microbial community compositions. In addition to tree species, initial soil properties and environmental factors significantly affect microbial communities (Brockett et al. 2012). In our study area, the initial levels of soil $\mathrm{C}$ and $\mathrm{N}$ content may have weakened the effects of tree species on soil microbial communities.

Although no significant change was found in fungal and bacterial abundances (except for bacterial abundances in the litter), microbial community compositions 
shifted in the mixed plantation. Our hypothesis that a mixed plantation can alter the structures and functions of microbial communities was confirmed. Several researchers have demonstrated that the structures of microbial communities are more sensitive than chemical parameters in response to changes in plant species (Gunina et al. 2017; Pereira et al. 2019). We observed that there are differences in the fungal and bacterial communities of forest litter and soil in monoculture and mixed-species plantations. Previous research has demonstrated that mixtures of Larix litter with broadleaved tree litter exhibited higher rate of litter decomposition than monoculture Larix litter. Specifically, mixing Larix litter with broadleaved litter could change the composition and function of the microbial community and improve the decomposition of hemicelluloses and lignin (Zhang et al. 2019). In contrast, soil that was mainly composed of fungal genera in the mixed plantation was only marginally different from that in the monoculture plantation. In addition, rare bacterial genera significantly contributed to the observed structural community differences. This result indicates that dominant bacterial genera are not sensitive to mixed plantations in temperate forest ecosystems; whereas, in evaluating bacterial community responses, rare bacterial genera were found to be critical. We also found that bacterial and fungal abundances decreased with soil depth, which is consistent with the results of other studies (Hartmann et al. 2009; Eilers et al. 2012).

\section{Conclusions}

The mixed-species plantations can significantly change the compositions and functions of microbial communities, but not the $\mathrm{C}$ and $\mathrm{N}$ contents, in comparison with monoculture plantations. Our study demonstrates that fungal communities are more sensitive than bacterial communities in responding to mixed plantations. Furthermore, compared to monoculture plantations, mixed-species plantations can significantly enhance soil available $\mathrm{N}$ and exoglucanase, $\beta$-glucosidase, and $N$-acetyl- $\beta$-glucosaminidase activity levels. Given that microorganisms are mediators of several important ecosystem functions, such as $\mathrm{C}$ and nutrient cycling, having mixed plantations might affect $\mathrm{C}$ and nutrient pools in the long term. In addition, our research suggests that fungal community compositions and enzyme activities are sensitive indicators of soil properties in mixed plantations that are more than 20 years old. In future, all these microbial properties should be considered in the selection of mixed tree species for soil restoration.

\section{Abbreviations}

C: Carbon; N: Nitrogen; PL: Monoculture L. gmelinii plantation; LF: Mixed plantation with L. gmelinii and F. mandshurica; PCA: Principal component analysis.

\section{Acknowledgements}

We are grateful to Jianqiang Xiao and Shaozhong Wang for assistance with litter and soil sample collection.

\section{Authors' contributions}

$\mathrm{KY}$ and JZ designed and ran the experiment, analyzed the data and wrote the manuscript. WZ and SX ran the experiment and analyzed the data. JG and ZW gave the help in running the experiment. All authors read and approved the final manuscript.

\section{Funding}

This study was financially supported by National Natural Science Foundation of China (31922059) and Key Research Program of Frontier Sciences, CAS (QYZDJ-SSW-DQC027 and ZDBS-LY-DQC019).

Availability of data and materials

Not applicable.

\section{Declarations}

Ethics approval and consent to participate

Not applicable.

Consent for publication

Not applicable.

Competing interests

The authors declare that they have no competing interests.

\section{Author details}

${ }^{1}$ CAS Key Laboratory of Forest Ecology and Management, Institute of Applied Ecology, Chinese Academy of Sciences, 72 Wenhua Road, Shenyang 110016, People's Republic of China. ${ }^{2}$ Qingyuan Forest CERN, Chinese Academy

of Sciences, 72 Wenhua Road, Shenyang 110016, People's Republic of China.

${ }^{3}$ University of Chinese Academy of Sciences, Beijing 100049, People's Republic of China. ${ }^{4}$ School of Forestry, Northeast Forestry University, Harbin 150040,

People's Republic of China.

Received: 31 August 2021 Accepted: 5 January 2022

Published online: 13 February 2022

References

Allison SD, Nielsen C, Hughes RF (2006) Elevated enzyme activities in soils under the invasive nitrogen-fixing tree Falcataria moluccana. Soil Biol Biochem 38:1537-1544

Bach LH, Grytnes J, Halvorsen R, Ohlson M (2010) Tree influence on soil microbial community structure. Soil Biol Biochem 42:1934-1943

Barbi F, Prudent E, Vallon L, Buée M, Dubost A, Legout A, Marmeisse R, Fraissinet-Tachet L, Luis P (2016) Tree species select diverse soil fungal communities expressing different sets of lignocellulolytic enzymeencoding genes. Soil Biol Biochem 100:149-159

Bohlen PJ, Groffman PM, Driscoll CT, Fahey TJ, Siccama TG (2001) Plantsoil-microbial interactions in a Northern hardwood forest. Ecology 82:965-978

Brassard BW, Chen HYH, Bergeron Y, Paré D (2011) Differences in fine root productivity between mixed- and single-species stands. Funct Ecol 25:238-246

Brockett BFT, Prescott CE, Grayston SJ (2012) Soil moisture is the major factor influencing microbial community structure and enzyme activities across seven biogeoclimatic zones in western Canada. Soil Biol Biochem 44:9-20

Burke DJ, Weintraub MN, Hewins CR, Kalisz S (2011) Relationship between soil enzyme activities, nutrient cycling and soil fungal communities in a northern hardwood forest. Soil Biol Biochem 43:795-803

Cheeke TE, Phillips RP, Brzostek ER, Rosling A, Bever JD, Fransson P (2017) Dominant mycorrhizal association of trees alters carbon and nutrient cycling by selecting for microbial groups with distinct enzyme function. New Phytol 214:432-442 
Chiti T, Diaz-Pinés E, Rubio A (2012) Soil organic carbon stocks of conifers, broadleaf and evergreen broadleaf forests of Spain. Biol Fertil Soils 48:817-826

Chodak M, Klimek B, Niklińska M (2016) Composition and activity of soil microbial communities in different types of temperate forests. Biol Fert Soils 52:1093-1104

Diers M, Weigel R, Culmsee H, Leuschner C (2021) Soil carbon and nutrient stocks under Scots pine plantations in comparison to European beech forests: a paired-plot study across forests with different management history and precipitation regimes. For Ecosyst 8:47

Dijkstra P, Ishizu A, Doucett R, Hart SC, Schwartz E, Menyailo OV, Hungate BA (2006) ${ }^{13} \mathrm{C}$ and ${ }^{15} \mathrm{~N}$ natural abundance of the soil microbial biomass. Soil Biol Biochem 38:3257-3266

Eilers KG, Debenport S, Anderson S, Fierer N (2012) Digging deeper to find unique microbial communities: the strong effect of depth on the structure of bacterial and archaeal communities in soil. Soil Biol Biochem 50:58-65

Esen A (1993) B-Glucosidases: overview. In: Esen A (ed) Beta-glucosidases: biochemistry and molecular biology. American Chemical Society, Washington, DC, pp 1-14

Gautam MK, Lee K, Song B, Bong Y (2017) Site related $\delta^{13} \mathrm{C}$ of vegetation and soil organic carbon in a cool temperate region. Plant Soil 418:293-306

Gilmore AR, Boggess WR (1963) Effects of past agricultural practices on the survival and growth of planted trees. Soil Sci Soc Am J 27:98-101

Gong ZT, Chen ZC, Luo GB, Zhang GL, Zhao WJ (1999) Soil reference with Chinese roil taxonomy. Soils 31:57-63 (in Chinese)

Guillaume T, Damris M, Kuzyakov Y (2015) Losses of soil carbon by converting tropical forest to plantations: erosion and decomposition estimated by $\delta^{13} \mathrm{C}$. Glob Change Biol 21:3548-3560

Gunina A, Smith AR, Godbold DL, Jones DL, Kuzyakov Y (2017) Response of soil microbial community to afforestation with pure and mixed species. Plant Soil 412:357-368

Harris J (2009) Soil microbial communities and restoration ecology: facilitators or followers? Science 325:573-574

Hartmann M, Lee S, Hallam SJ, Mohn WW (2009) Bacterial, archaeal and eukaryal community structures throughout soil horizons of harvested and naturally disturbed forest stands. Environ Microbiol 11:3045-3062

Hobbie EA, Ouimette AP (2009) Controls of nitrogen isotope patterns in soil profiles. Biogeochemistry 95:355-371

Huang ZQ, Wan XH, He ZM, Yu ZP, Wang MH, Hu ZH, Yang YS (2013) Soil microbial biomass, community composition and soil nitrogen cycling in relation to tree species in subtropical China. Soil Biol Biochem 62:68-75

Huang XM, Liu SR, Wang H, Hu ZD, Li ZG, You YM (2014) Changes of soil microbial biomass carbon and community composition through mixing nitrogen-fixing species with Eucalyptus urophylla in subtropical China. Soil Biol Biochem 73:42-48

Kaiser C, Koranda M, Kitzler B, Fuchslueger L, Schnecker J, Schweiger P, Rasche F, Zechmeister-Boltenstern S, Sessitsch A, Richter A (2010) Belowground carbon allocation by trees drives seasonal patterns of extracellular enzyme activities by altering microbial community composition in a beech forest soil. New Phytol 187:843-858

Kooch Y, Bayranvand M (2017) Composition of tree species can mediate spatial variability of $\mathrm{C}$ and $\mathrm{N}$ cycles in mixed beech forests. Forest Ecol Manag 401:55-64

Li H, Ye DD, Wang XG, Settles ML, Wang J, Hao ZQ, Zhou LS, Dong P, Jiang Y, Ma ZS (2014) Soil Bacterial communities of different natural forest types in Northeast China. Plant Soil 383:203-216

Liu CM, Kachur S, Dwan MG, Abraham AG, Aziz M, Hsueh PR, Huang YT, Busch JD, Lamit LJ, Gehring CA, Keim P, Price LB (2012) FungiQuant: a broadcoverage fungal quantitative real-time PCR assay. BMC Microbiol 12:255

Liu Y, Lei PF, Xiang WH, Yan WD, Chen XY (2017) Accumulation of soil organic C and $\mathrm{N}$ in planted forests fostered by tree species mixture. Biogeosciences 14:3937-3945

Liu Y, Shen X, Chen YM, Wang LF, Chen QM, Zhang J, Xu ZF, Tan B, Zhang L, Xiao JJ, Zhu P, Chen LH (2019) Litter chemical quality strongly affects forest floor microbial groups and ecoenzymatic stoichiometry in the subalpine forest. Ann Forest Sci 76:106

Lucas-Borja ME, Candel D, Jindo K, Moreno JL, Andrés M, Bastida F (2012) Soil microbial community structure and activity in monospecific and mixed forest stands, under Mediterranean humid conditions. Plant Soil 354:359-370
Mei L, Wang ZQ, Cheng YH, Han YZ, Zhang ZW (2008) Relationships between fine roots distribution and soil nitrogen availability in Manchurian ash and Korean larch plantation. J Huazhong Agricul Univer 27:117-121 (in Chinese with English Abstract)

Parham JA, Deng SP (2000) Detection, quantification and characterization of $\beta$-glucosaminidase activity in soil. Soil Biol Biochem 32:1183-1190

Pei ZQ, Eichenberg D, Bruelheide H, Kröber W, Kühn P, Li Y, von Oheimb G, Purschke O, Scholten T, Buscot F, Gutknecht JLM (2016) Soil and tree species traits both shape soil microbial communities during early growth of Chinese subtropical forests. Soil Biol Biochem 96:180-190

Pereira APA, Durrer A, Gumiere T, Goncalves JLM, Robin A, Bouillet J-P, Wang J, Verma JP, Singh BK, Cardoso EJBN (2019) Mixed Eucalyptus plantations induce changes in microbial communities and increase biological functions in the soil and litter layers. Forest Ecol Manag 433:332-342

Rachid CTCC, Balieiro FC, Peixoto RS, Pinheiro YAS, Piccolo MC, Chaer GM, Rosado AS (2013) Mixed plantations can promote microbial integration and soil nitrate increases with changes in the $\mathrm{N}$ cycling genes. Soil Biol Biochem 66:146-153

Saiya-Cork KR, Sinsabaugh RL, Zak DR (2002) The effects of long-term nitrogen deposition on extracellular enzyme activity in an Acer saccharum forest soil. Soil Biol Biochem 34:1309-1315

Singh K, Singh B, Singh RR (2012) Changes in physico-chemical, microbial and enzymatic activities during restoration of degraded sodic land: ecological suitability of mixed forest over monoculture plantation. Catena 96:57-67

State Forest Administration (2014) Report of forest resources in China (2009-2013). China Forestry Press, Beijing (in Chinese)

Stone MM, DeForest JL, Plante AF (2014) Changes in extracellular enzyme activity and microbial community structure with soil depth at the Luquillo Critical Zone Observatory. Soil Biol Biochem 75:237-247

Tabatabai MA (1994) Soil enzymes. In: Weaver RW, Angle JS, Bottomley PS (eds) Methods of soil analysis. Part 2. Microbiological and biochemical properties. SSSA Book Series No. 5. Soil Science Society of America, Madison, pp 775-833

Takai K, Horikoshi K (2000) Rapid detection and quantification of members of the archaeal community by quantitative PCR using fluorogenic probes. Appl Environ Microb 66:5066-5072

Thoms C, Gattinger A, Jacob M, Thomas FM, Gleixner G (2010) Direct and indirect effects of tree diversity drive soil microbial diversity in temperate deciduous forest. Soil Biol Biochem 42:1558-1565

Trasar-Cepeda C, Leirós MC, Gil-Sotres F (2008) Hydrolytic enzyme activities in agricultural and forest soils. Some implications for their use as indicators of soil quality. Soil Biol Biochem 40:2146-2155

Urbanová M, Šnajdr J, Baldrian P (2015) Composition of fungal and bacterial communities in forest litter and soil is largely determined by dominant trees. Soil Biol Biochem 84:53-64

Venkatesan S, Senthurpandian VK (2006) Comparison of enzyme activity with depth under tea plantations and forest sites in south India. Geoderma 137:212-216

Wang ZQ, Guo DL, Wang XR, Gu JC, Mei L (2006) Fine root architecture, morphology and biomass, of different branch orders of two Chinese temperate tree species. Plant Soil 288:155-171

Wardle DA, Bardgett RD, Klironomos JN, Setälä H, van der Putten WH, Wall $\mathrm{DH}$ (2004) Ecological linkages between aboveground and belowground Biota. Science 304:1629-1633

Weand MP, Arthur MA, Lovett GM, McCulley RL, Weathers KC (2010) Effects of tree species and $\mathrm{N}$ additions on forest floor microbial communities and extracellular enzyme activities. Soil Biol Biochem 42:2161-2173

White TJ, Bruns T, Lee S, Taylor J (1990) Amplification and direct sequencing of fungal ribosomal RNA genes for phylogenetics. In: Innis MA, Gelfand DH, Sninsky JJ, White TJ (eds) PCR Protocols: a guide to methods and applications. Academic Press, New York, pp 315-322

Xu HD, Yu MK, Cheng XR (2021) Abundant fungal and rare bacterial taxa jointly reveal soil nutrient cycling and multifunctionality in unevenaged mixed plantations. Ecol Indic 129:107932

Yang K, Zhu JJ, Yan QL, Sun JX (2010) Changes in soil P chemistry as affected by conversion of natural secondary forests to larch plantations. Forest Ecol Manag 260:422-428

Yang K, Shi W, Zhu JJ (2013) The impact of secondary forests conversion into larch plantations on soil chemical and microbiological properties. Plant Soil 318:535-546 
Yu Y, Lee C, Kim J, Hwang S (2005) Group-specific primer and probe sets to detect methanogenic communities using quantitative real-time polymerase chain reaction. Biotechnol Bioeng 89:670-679

Yu X, Liu X, Zhao Z, Liu JL, Zhang SX (2015) Effect of monospecific and mixed sea-buckthorn (Hippophae rhamnoides) plantations on the structure and activity of soil microbial communities. PLOS ONE 10:e0117505

Zhang WW, Lu ZT, Yang K, Zhu JJ (2017) Impacts of conversion from secondary forests to larch plantations on the structure and function of microbial communities. Appl Soil Ecol 111:73-83

Zhang WW, Yang K, Lu ZT, Zhu JJ (2019) Microbial groups and their functions control the decomposition of coniferous litter: a comparison with broadleaved tree species. Soil Biol Biochem 133:196-207

Zhang YT, Ding K, Yrjälä K, Liu HY, Tong ZK, Zhang JH (2021) Introduction of broadleaf species into monospecific Cunninghamia lanceolata plantations changed the soil Acidobacteria subgroups composition and nitrogen-cycling gene abundances. Plant Soil 467:29-46

\section{Publisher's Note}

Springer Nature remains neutral with regard to jurisdictional claims in published maps and institutional affiliations.

\section{Submit your manuscript to a SpringerOpen ${ }^{\circ}$ journal and benefit from:}

- Convenient online submission

- Rigorous peer review

- Open access: articles freely available online

- High visibility within the field

- Retaining the copyright to your article

Submit your next manuscript at $\boldsymbol{\nabla}$ springeropen.com 